\title{
$\alpha-$-1-Antitrypsin metabolism in the protein-deficient weanling rat
}

\author{
BY ERIC C. LEWIS*, ROBERT H. GLEW†, JAMES CHAMBERSł, \\ PATRICK COYLE AND JOHN COPPES \\ Department of Biochemistry, University of Pittsburgh School of Medicine, \\ Pittsburgh, PA 15261, USA
}

\section{(Received 13 August 1984 - Accepted 15 February 1985)}

1. Protein-deficient weanling rats fed on a $30 \mathrm{~g}$ casein/ $\mathrm{kg}$ diet for 3 weeks lost albumin but maintained the level of serum $\alpha$-1-antitrypsin, the most abundant protease inhibitor in blood.

2. $\alpha$-1-Antitrypsins from malnourished rats and control rats (given $250 \mathrm{~g}$ casein $/ \mathrm{kg}$ diet) differed; the protease inhibitor from protein-deficient animals: (1) was more acidic, (2) appeared slightly larger (57400 v. 56000 daltons) on sodium dodecyl sulphate (SDS)-polyacrylamide gels, (3) had a more acidic $\mathrm{P}_{1}$ type and increased anodal mobility at $\mathrm{pH} 8.9$, (4) bound more concanavalin-A and contained more carbohydrate, specifically two to three extra sialic acid residues. The amino sugar and neutral sugar contents of both preparations of $\alpha-1$-antitrypsin were the same.

3. Analysis of the products of cyanogen-bromide cleavage revealed that $\alpha$-1-antitrypsin preparations from protein-deficient rats contain an extra glycopeptide that was not present in $\alpha-1$-antitrypsin from control animals.

4. In vivo studies showed that the increased sialic acid content of $\alpha$-1-antitrypsin of protein-deficient rats did not alter the half-life of the molecule in the blood of control rats. However, the fractional catabolic rate of $\alpha$-1-antitrypsin from either well-nourished or protein-deficient rats was significantly $(P<0.01)$ lower in proteindeficient rats than in control rats $(0 \cdot 0247 / \mathrm{h} v .0 \cdot 0406 / \mathrm{h})$.

5. The decreased fractional catabolic rate could not be explained by changes in hepatic mannosyl-, galactosylor $\mathrm{N}$-acetylhexosaminyl receptors since liver perfusion studies showed that bovine serum albumin, when covalently modified separately with each of these ligands, was extracted from the perfusion medium as rapidly or more rapidly by livers from malnourished animals.

6. Perfused livers from protein-deficient rats secrete three times more $\alpha$-1-antitrypsin than do livers from well-nourished animals.

7. The decreased fractional catabolic rate and increased rate of biosynthesis and secretion of the glycoprotein by livers from protein-deficient animals may account for the maintenance of $\alpha-1$-antitrypsin levels during protein malnutrition.

The major protease inhibitor in mammalian plasma is $\alpha$-1-antitrypsin (Rosenberg et al. 1976; Hodges et al. 1979; Takahara et al. 1980). It has been demonstrated that children with marasmus or kwashiorkor maintain their plasma level of $\alpha$-1-antitrypsin in the face of a decreasing albumin concentration (Omene et al. 1979b; Schelp et al. 1981). We were interested in examining fractional catabolic rates and secretion of the glycoprotein in an experimental animal, namely the weanling rat, free from the problems of infection (e.g. measles and parasites) and deficiencies of other essential dietary factors (e.g. vitamins) that often complicate the interpretation of results of field studies involving humans. In order to compare the fractional catabolic rate of radiolabelled $\alpha-1$-antitrypsin in control and protein-deficient weanling rats, pure preparations of $\alpha$-1-antitrypsin from serum of both kinds of animals were required. In the process of purifying $\alpha$-1-antitrypsin from proteinmalnourished rats and in establishing the purity of the preparation, we noticed that the glycoprotein was different from $\alpha$-1-antitrypsin from control animals. In the present report, we show that this difference appears to lie in the carbohydrate domain. We also show that in the face of a decrease in plasma albumin concentration, the profoundly protein malnourished rat maintains its plasma $\alpha-1$-antitrypsin level by substantially decreasing the fractional catabolic rate of the molecule and increasing its rate of secretion from the liver.

Present addresses: * Office of Student Affairs, University of Pennsylvania, School of Medicine, Philadelphia, PA 19104, USA. $\ddagger$ Department of Pediatrics, University of Texas Health Sciences Center at Houston Medical School, Houston, TX 77025, USA.

$\dagger$ For reprints. 


\section{EXPERIMENTAL}

Animals and diets. Weanling Sprague-Dawley rats $(21 \mathrm{~d}$ old $)$ were given a $250 \mathrm{~g}$ casein $/ \mathrm{kg}$ diet for 1 week. Animals were housed individually for determination of food consumption. Beginning on day 28, the protein-deficient experimental group was given a $30 \mathrm{~g}$ casein $/ \mathrm{kg}$ diet; the composition of the diet has been described previously (Bieri et al. 1977; Glew et al. 1982). The control group was given a diet that was identical to that given to the experimental group except that the casein content was increased to $250 \mathrm{~g} / \mathrm{kg}$ at the expense of sucrose.

Determination of trypsin inhibitory capacity. Trypsin-inhibitory capacity (TIC) was determined as described by Eriksson (1965) using crystalline trypsin (Worthington Biochemical Corp., Freehold, New Jersey, USA) and benzoyl-L-arginine-p-nitroanilide as the trypsin substrate. TIC is expressed as $\mathrm{mg}$ trypsin inhibited $/ \mathrm{ml}$. The number of active sites in each trypsin preparation was determined according to the method of Chase \& Shaw (1967).

Protein determinations. The concentration of rat albumin in the perfusion medium was determined by the rocket immunoelectrophoresis assay of Laurell (1972) using commercial goat anti-rat albumin antibody with normal rat serum of known albumin concentration serving as the standard. The albumin content of serum was determined by the dye-binding method of Doumas et al. (1971) using human serum albumin as standard. Unless otherwise specified, total protein was determined according to the procedure of Bradford (1976) using bovine serum albumin as standard. During the purification of $\alpha$-1-antitrypsin, column fractions were monitored for protein by u.v. absorption (Warburg \& Christian, 1941).

Purification of $\alpha$-1-antitrypsin. The isolation of $\alpha$-1-antitrypsin from control and proteindeficient rats was performed by a modification of the method described by Takahara et al. (1980). We used an Affi-Gel Blue (Bio-Rad Inc., Richmond, Virginia, USA) column instead of Cibacron Blue agarose, omitted the $\mathrm{pH} 6.0 \mathrm{DE}-52$ cellulose column step, and used an activated thiol-Sepharose column after the Sephadex G-150 step. The thiol-Sepharose column was used exactly as described by Laurell (1978). The yield of $\alpha$-1-antitrypsin from plasma of control and protein-deficient rats was $20-25 \%$. The specific activities of the final preparations from both kinds of animals were indistinguishable, ranging from 0.50 to $0.56 \mathrm{mg}$ trypsin inhibited $/ \mathrm{mg}$ protein; the theoretical value is $0.53 \mathrm{mg}$ based on a binding ratio for $\alpha-1$-antitrypsin and trypsin of $1: 1$.

Analytical polyacrylamide-gel electrophoresis. Polyacrylamide-gel electrophoresis was performed under non-denaturing conditions as described by Davis (1964), and in the presence of sodium dodecyl sulphate (SDS) as described by Laemmli (1970). Gels were stained for protein with Coomassie brilliant blue and for carbohydrate using the periodic acid-Schiff's stain of Kapitany \& Zebrowski (1973).

Analytical electrofocusing on polyacrylamide gels. Comparison of $\alpha$-1-antitrypsin preparations by electrofocusing ( $\mathbf{P}_{\mathbf{i}}$ typing) was performed according to the procedure of Jeppsson \& Boel (1982).

Amino acid analysis. The amino acid composition of purified $\alpha$-1-antitrypsin preparations was determined as follows: an acid hydrolysate of the protein was prepared by digesting samples in $6 \mathrm{M}$-hydrochloric acid at $100^{\circ}$ in vacuo for 24 and $48 \mathrm{~h}$ as described by Moore \& Stein (1963). Amino acids were determined using a Beckman model 120 amino acid analyser according to the procedure of Spackman et al. (1958).

Carbohydrate analysis. Neutral sugars were determined after hydrolysis of $\alpha$-1-antitrypsin preparations in $3 \mathrm{M}-\mathrm{HCl}$ for $3 \mathrm{~h}$ at $100^{\circ}$. Amino sugars were determined after hydrolysis of a $1 \mathrm{mg}$ sample in $3 \mathrm{M}-\mathrm{HCl}$ for $6 \mathrm{~h}$ at $100^{\circ}$. Quantitative analysis of neutral sugars and amino sugars was performed as described by Takasaki \& Kobata (1976). The samples were 
subjected to sodium $\left[{ }^{3} \mathrm{H}\right]$ borohydride reduction followed by separation of the reduced sugars by descending paper chromatography. Sialic acid was measured using the thiobarbituric acid method of Warren (1959) with $N$-acetylneuraminic acid serving as standard.

Concanavalin- $A$ reactivity of $\alpha$-1-antitrypsin from control and protein-deficient rats. Concanavalin- $\mathrm{A}(2 \mathrm{mg})$ was labelled with $\mathrm{NaB}^{3} \mathrm{H}_{4}$ using the procedure of Rice \& Means (1971). ${ }^{3} \mathrm{H}$-Labelled concanavalin-A was reacted with varying amounts of pure $\alpha-1$ antitrypsin from control and malnourished animals. The standard reaction mixture contained $133 \mu \mathrm{g}{ }^{3} \mathrm{H}$-labelled concanavalin-A, $10-50 \mu \mathrm{g} \alpha$-1-antitrypsin in $0.6 \mathrm{ml} 20 \mathrm{~mm}$ sodium phosphate buffer, $\mathrm{pH} 7.0$, containing $0.2 \mathrm{M}$-sodium chloride. After $50 \mathrm{~min}$ at $20^{\circ}$, the reaction mixture was diluted with $2 \mathrm{ml}$ of the same saline-phosphate buffer and filtered through a Millipore glass-fibre filter. The precipitate was washed with $20 \mathrm{ml}$ of the same buffer and counted for radioactivity in a liquid scintillation spectrometer.

Galactose oxidase ( $E C$ 1.1.3.9)- $\mathrm{NaB}^{3} \mathrm{H}_{4}$ labelling. An effort was made to radiolabel exposed galactose and $N$-acetylgalactosamine residues in $\alpha$-1-antitrypsin preparations using the procedure of Critchley et al. (1981). $\mathrm{NaB}^{3} \mathrm{H}_{4}(300 \mathrm{mCi} / \mathrm{mmol})$ was purchased from New England Nuclear, Boston, Massachusetts, USA.

Cyanogen bromide cleavage of $\alpha$-1-antitrypsin. The reduction, alkylation and cleavage of $\alpha-1$-antitrypsin were performed as described by Roll et al. (1978). Lyophilized fragments were resuspended in distilled water and adjusted to $\mathrm{pH} 9.0$ with dilute ammonium hydroxide.

Iodination of $\alpha$-1-antitrypsin. Purified rat $\alpha$-1-antitrypsin preparations were iodinated with carrier-free $\mathrm{Na}^{125}$ ( New England Nuclear) using Iodogen (Pierce Chemical Co., Rockford, Illinois, USA) as catalyst as described by Salacinski et al. (1979). Free ${ }^{125}$ I-labelled and iodinated $\alpha-1$-antitrypsin were separated by chromatography on a Sephadex G-25 column $(5 \times 250 \mathrm{~mm})$ equilibrated with $0.13 \mathrm{M}-\mathrm{NaCl}$. Iodinated preparations were then diluted with unlabelled $\alpha$-1-antitrypsin to give $6 \times 10^{6}$ counts $/ \mathrm{min}$ and $0 \cdot 01 \mathrm{mg}$ protein $/ 0 \cdot 1 \mathrm{ml}$. Animals were injected via the tail vein with $1 \mathrm{ml}$ iodinated $\alpha-1$-antitrypsin $/ \mathrm{kg}$ body weight. At various times, $20 \mu \mathrm{l}$ blood were withdrawn from the tail vein by lancing the tip of the tail with a razor blade. Blood samples were counted for radioactivity in a Packard model $800 \mathrm{C}$ gamma counter.

Determination of $\alpha$-1-antitrypsin concentration. The mass of $\alpha-1$-antitrypsin in serum or portions of perfusate was determined by the rocket immunoelectrophoresis procedure of Laurell (1972), using rabbit anti-rat $\alpha-1$-antitrypsin antisera with pure $\alpha$-1-antitrypsin from control rats serving as the standard.

Perfusion. Liver perfusion was carried out exactly as described by Glew et al. (1982). $\beta$-Galactosyl-bovine serum albumin (BSA) (39 mol/mol protein), $\alpha$-mannosyl - BSA (33 $\mathrm{mol} / \mathrm{mol}$ protein) and $\beta$ - $N$-acetylglucosaminyl-BSA ( $36 \mathrm{~mol} / \mathrm{mol}$ protein) were a gift from Dr Y. C. Lee. The anaesthetic, sodium nembutal, was from Abbot Laboratories. The Teflon Quick-Cath intravenous placement units used for cannulation were from Vicra, a Division of Travenol Laboratories. Outdated human blood was generously provided by the Central Blood Bank of Pittsburgh. The oxygen-carbon dioxide $(95: 5, \mathrm{v} / \mathrm{v})$ gas mixture used for oxygenation was provided by Specialty Air Products, Pittsburgh, PA.

\section{RESULTS}

Description of protein-deficient animals. A detailed description of the changes in food consumption, body-weight, organ weights, plasma albumin and amino acids, and tissue and serum lysosomal hydrolase activities during the course of the experiment is provided elsewhere (Glew et al. 1982). In the present study, on the 28 th day after birth, at the time the animals were placed on the experimental diet, their average body-weight was $90 \mathrm{~g}$. After 
Table 1. Changes in the concentration of various serum proteins in control and protein-deficient weanling rats

(Mean values and standard deviations for three rats/group)

\begin{tabular}{|c|c|c|c|c|c|c|}
\hline \multirow[b]{2}{*}{ Serum index } & \multicolumn{2}{|c|}{ Control } & \multicolumn{2}{|c|}{ Protein-deficient* } & \multicolumn{2}{|c|}{ Rehabilitated $\dagger$} \\
\hline & Mean & SD & Mean & SD & Mean & SD \\
\hline Albumin $(\mathrm{g} / 1)$ & 3.05 & $0 \cdot 29$ & $2 \cdot 1$ & $0 \cdot 18$ & $2 \cdot 9$ & 0.35 \\
\hline $\begin{array}{l}\text { Protease inhibitor, TIC (mg trypsin } \\
\text { inhibited/ml serum) } \\
\alpha \text {-1-Antitrypsin } \ddagger(\mathrm{mg} / \mathrm{ml})\end{array}$ & $\begin{array}{l}0.70 \\
1.90\end{array}$ & $\begin{array}{l}0.09 \\
0.06\end{array}$ & $\begin{array}{l}0.87 \\
2 \cdot 90\end{array}$ & $\begin{array}{l}0.13 \\
0.67\end{array}$ & $\begin{array}{l}0.81 \\
1.90\end{array}$ & $\begin{array}{l}0 \cdot 00 \\
0 \cdot 10\end{array}$ \\
\hline
\end{tabular}

TIC, trypsin inhibitory capacity.

* Protein-deficient animals were given the $30 \mathrm{~g}$ casein $/ \mathrm{kg}$ diet for 3 weeks.

$\dagger$ After 3 weeks on the $30 \mathrm{~g}$ casein $/ \mathrm{kg}$ diet, the experimental animals were given the control diet $(250 \mathrm{~g}$ casein $/ \mathrm{kg}$ diet) for 1 week.

$\ddagger$ Determined immunologically by radial immunodiffusion.

consuming the $30 \mathrm{~g}$ casein $/ \mathrm{kg}$ diet for 4 weeks the average weight of the experimental group was $70 \mathrm{~g}$. The control group of rats fed on the $250 \mathrm{~g}$ casein $/ \mathrm{kg}$ diet gained weight linearly over the same time period such that after 4 weeks their weight averaged $275 \mathrm{~g}$.

Changes in serum $\alpha-1$-antitrypsin and albumin concentration in protein-deficient weanling rats. After the protein-deficient animals had been consuming the $30 \mathrm{~g}$ casein $/ \mathrm{kg}$ diet for 3 weeks, their serum albumin concentration decreased by nearly one-third (Table 1). However, the protein-deficient animals had maintained the plasma level of their principal plasma protease inhibitor: the mean serum TIC value was $0 \cdot 87$ for the experimental animals and $\mathbf{0 . 7 0}$ for the control animals. These results are in agreement with observations that there is no decrease in the trypsin inhibitory capacity of serum from children with marasmus or kwashiorkor (Omene et al. 1979b).

The mass of $\alpha$-1-antitrypsin was estimated directly using an immunologic assay. With the aid of the radial immunodiffusion technique (Mancini et al. 1965) and rabbit antibody directed against a pure preparation of rat $\alpha$-1-antitrypsin, we estimated $\alpha-1$-antitrypsin titres of 2.9 and $1.9 \mathrm{mg} / \mathrm{ml}$ in the protein-deficient and control groups respectively. Within 1 week of instituting nutritional rehabilitation, the serum indices listed in Table 1 had returned to control values.

Based on the known stoichiometry between $\alpha-1$-antitrypsin and trypsin $(1: 1)$ in the protease inhibitor-protease complex, the quantity of serum $\alpha$-1-antitrypsin estimated by the immunologic technique exceeded that based on the results of TIC determinations. For example, if all the antitrypsin activity in serum from control animals $(0.70 \mathrm{TIC})$ was due to $\alpha$-1-antitrypsin, this would correspond to about $1.40 \mathrm{mg} \alpha-1$-antitrypsin/ml. The difference between the estimates of $\alpha$-1-antitrypsin concentration by the two methods $(1.40$ $v .1 .90 \mathrm{mg} / \mathrm{ml}$ ) could be accounted for by the presence of circulating forms of the protease inhibitor which were incapable of inhibiting trypsin.

Comparison of electrophoretic properties of purified $\alpha$-1-antitrypsin preparations from control and protein-deficient rats. $\alpha$-1-Antitrypsin was purified from serum obtained from protein-deficient rats after they had been consuming the $30 \mathrm{~g}$ casein $/ \mathrm{kg}$ diet for 4 weeks. The final preparation of $\alpha-1$-antitrypsin exhibited a molar combining ratio of $1: 1$ with trypsin and ran as a single, broad band when subjected to electrophoresis in polyacrylamide gels under non-denaturing conditions (Fig. 1). The relative diffuseness of the band is not unexpected for a glycoprotein known to be composed of microheterogeneous species (Takahara et al. 1980). In five different experiments, $\alpha$-1-antitrypsin from the protein-deficient 


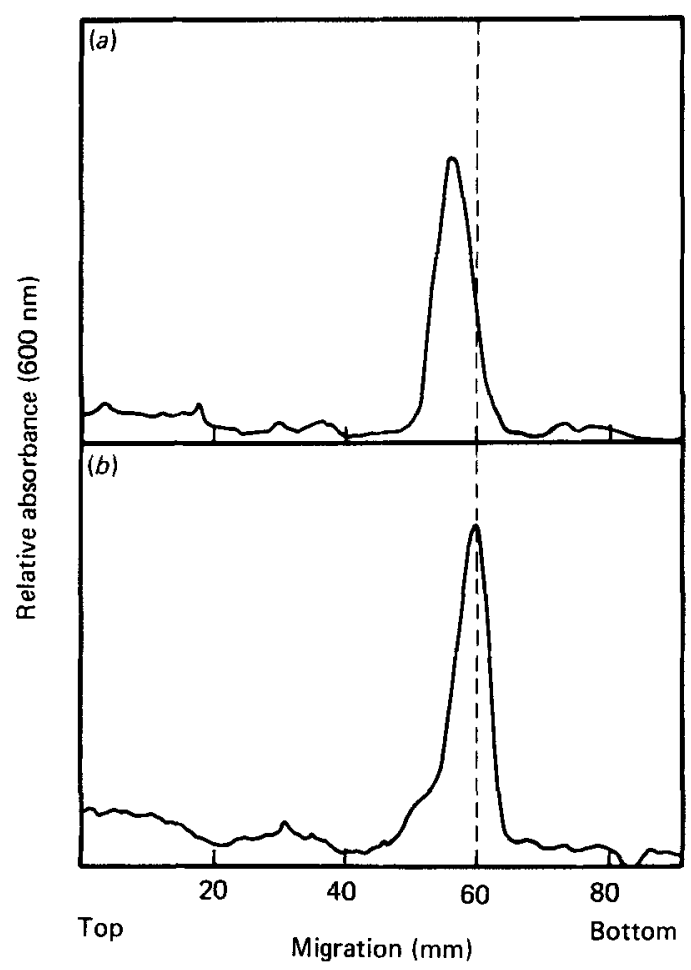

Fig. 1. Comparison of purified rat $\alpha$-1-antitrypsins by native polyacrylamide gel electrophoresis. Final preparations of $\alpha$-1-antitrypsin $(20 \mu \mathrm{g})$ from $(a)$ controls and $(b)$ protein-deficient animals were subjected to electrophoresis in a 1:9 (w/v) polyacrylamide slab gel in the absence of SDS as described on p. 64). The gel was stained for protein and scanned for absorbance at $600 \mathrm{~nm}$ using a Gilford linear transport.

animals moved significantly $(P<0.001)$ closer to the anode than did the same protein derived from serum of control animals $(60.0$ (SD 1) $\mathrm{mm} v .55 .5$ (SD 0.8) $\mathrm{mm}$ ). This change in electrophoretic mobility could be the result of differences in the net negative charge, size or carbohydrate content of the two $\alpha-1$-antitrypsins. In an effort to gain insight into the basis for this change, we compared, under denaturing conditions, the electrophoretic mobilities of the $\alpha-1$-antitrypsin preparations from control and protein-deficient rats. Both proteins ran as single, somewhat diffuse bands in SDS-polyacrylamide slab gels (results not shown). However, in three separate experiments, $\alpha$-1-antitrypsin from the proteindeficient rats exhibited a slight but significantly lower $(P<0.001)$ electrophoretic mobility than the corresponding protein from rats given the $250 \mathrm{~g}$ casein $/ \mathrm{kg}$ diet; the difference in apparent molecular weights corresponded to 1400 daltons. These results suggest that the protease inhibitor from malnourished animals is slightly larger than the corresponding one from control animals; since $\alpha$-1-antitrypsin is a glycoprotein, the larger size could be due to the presence of additional peptide or carbohydrate in the molecule.

In the present study, $\alpha-1$-antitrypsin from control animals exhibited a higher apparent molecular weight (57000 daltons) in SDS-containing gels than it did in an earlier study (47000 daltons) (Roll \& Glew, 1981); this discrepancy could be due to the different molecular weight standards and polyacrylamide gel concentrations used in the two studies.

To compare further the physical and chemical properties of the two protease-inhibitor 


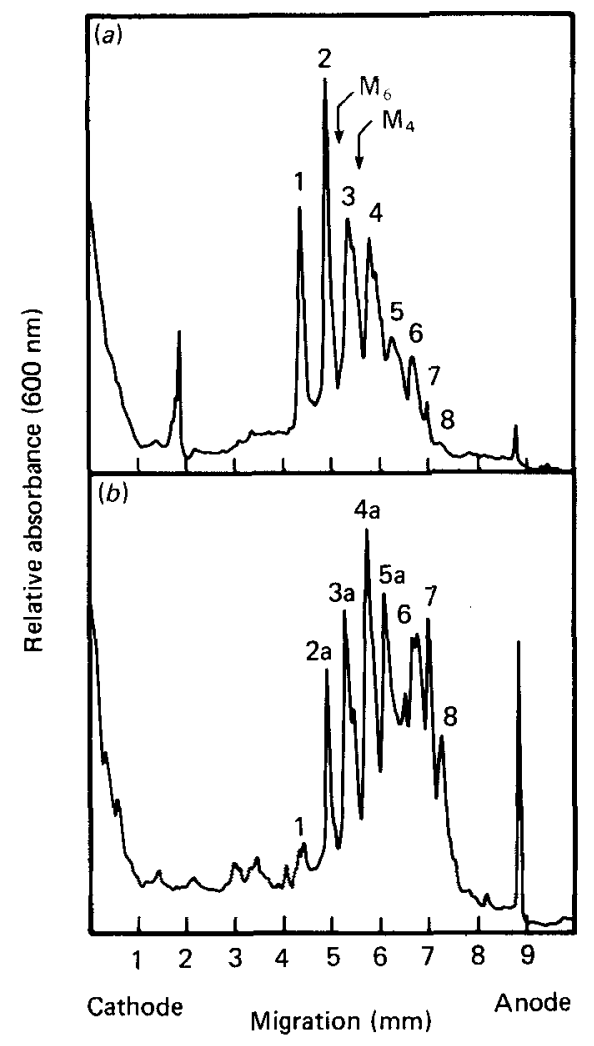

Fig. 2. Isoelectric focusing ( $P_{1}$ typing) of $\alpha$-1-antitrypsin in polyacrylamide gel. Samples of purified $\alpha$-1-antitrypsin from $(a)$ control and $(b)$ protein-deficient rats were subjected to isoelectric focusing in polyacrylamide slab gels. The pH range was $4 \cdot 0-5 \cdot 0$. The gel was stained for protein with the Coomassie reagent and scanned for absorbance at $600 \mathrm{~nm}$ with the aid of a Gilford linear transport. Human serum from a person with the $(M, M) P_{i}$ type was run as an internal standard; bands $M_{4}(p I, 4 \cdot 51)$ and $M_{6}$ (pI, 4.59) are noted for reference.

preparations, we subjected them (side-by-side) to isoelectric focusing ( $P_{i}$ typing) by means of slab electrophoresis in polyacrylamide gels (Fig. 2). $\alpha$-1-Antitrypsin from healthy rats (Fig. 2(a)) exhibited four major bands in the $\mathrm{pH} 4 \cdot 3-4 \cdot 8$ region, with several additional minor bands appearing closer to the anode. $\alpha$-1-Antitrypsin from protein-deficient rats (Fig. $2(b)$ ) also exhibited marked microheterogeneity and was distinctly more acidic than the protease inhibitor from control animals; it contained only a trace of species 1 that was prominent in $\alpha$-1-antitrypsin from controls. This observation is consistent with the results of polyacrylamide gel electrophoresis where the increased acidic character of $\alpha-1$-antitrypsin from protein-deficient animals was apparent (Fig. 1).

Amino acid and carbohydrate compositions. In an effort to explain the differences in the electrophoretic properties of the $\alpha$-1-antitrypsin preparations from normal and proteindeficient rats, we compared their amino acid and carbohydrate compositions (values not shown). Amino acid analyses were performed in duplicate after 24 and $48 \mathrm{~h}$ of hydrolysis. The amino acid composition of $\alpha$ - 1 -antitrypsin from control animals was in good agreement with that reported previously (Roll \& Glew, 1981). In the present study, we did not find a significant difference between the amino acid compositions of $\alpha$-1-antitrypsins from control and malnourished rats. Based on the results of triplicate analyses of various sugars, 
Table 2. Comparison of the carbohydrate compositions of $\alpha$-1-antitrypsin from control and protein-deficient rats*

\begin{tabular}{lcc}
\hline \hline Source of $\alpha$-1-antitrypsin... & Control & Protein-deficient $\dagger$ \\
\hline N-Acetylglucosamine & $8 \cdot 2$ & $7 \cdot 8$ \\
Mannose & $6 \cdot 4$ & $5 \cdot 9$ \\
Galactose & $2 \cdot 8$ & $3 \cdot 0$ \\
Sialic acid $\$$ & $5 \cdot 5$ & $8 \cdot 4$ \\
\hline \hline
\end{tabular}

* Control and protein-deficient animals were given 250 and $30 \mathrm{~g}$ casein $/ \mathrm{kg}$ diet respectively for 3 weeks.

$\dagger$ Residue values represent the average of 24 and $48 \mathrm{~h}$ hydrolysis, each done in duplicate. One mol is defined as $45100 \mathrm{~g}$ protein.

$\mp$ Sialic acid determined as thiobarbituric acid assay as described by Warren (1959). The difference in sialic acid content was significant $(P<0 \cdot 005)$.

we observed no significant differences in the glucosamine, galactose or mannose contents of protease inhibitor preparations from control and experimental animals (Table 2). However, based on the results of four separate determinations, we did find significantly $(P<0.005)$ more sialic acid in the $\alpha-1$-antitrypsin derived from serum of protein-deficient rats; this increase amounted to two to three residues of sialic acid/mol protein. Neither preparation of rat $\alpha-1$-antitrypsin contained fucose or galactosamine.

The finding of two to three additional sialic acid residues in the $\alpha$-1-antitrypsin preparation from malnourished animals could account for the slightly larger apparent size of the molecule compared with $\alpha$-1-antitrypsin from control rats. Furthermore, the extra sialic acid could account for the increased anodal mobility of the $\alpha$-1-antitrypsin from malnourished animals, as well as for the shift in the isoelectric focusing pattern to a more acidic $\mathrm{pH}$ range (Fig. 2).

Cyanogen bromide fingerprints. We approached the question of the possible presence of an additional oligosaccharide chain in $\alpha$-1-antitrypsin from protein-deficient rats using a combination of cyanogen bromide cleavage and SDS-polyacrylamide slab gel electrophoresis (Fig. 3). Based on the methionine content of nine residues/mol rat $\alpha$-1-antitrypsin, cyanogen bromide cleavage should generate a total of ten glycopeptides and peptides. As shown in Fig. 3, Coomassie brilliant blue-stained electrophoretograms of cyanogen bromide digests of $\alpha$-l-antitrypsin preparations from control (Fig. 3(c)) and protein-deficient animals (Fig. 3(d)) yielded identical patterns, each one demonstrating ten bands. However, when replicate gels were stained for carbohydrate with the periodic acid-Schiff's stain, a clear difference was observed. Cyanogen bromide digests of $\alpha$-l-antitrypsin from protein-deficient rats (Fig. 3(b)) contained three prominent glycopeptides (peaks 2, 3 and 7). In contrast, only two major glycopeptides were observed in the $\alpha$-l-antitrypsin preparation from control animals (Fig. 3(a), peaks 2 and 7) with a slight shoulder appearing on the trailing edge of peak 7.

Concanavalin-A reactivity of $\alpha$-1-antitrypsin preparations. The finding of differences in the carbohydrate compositions of $\alpha$-1-antitrypsin from experimental and control animals prompted us to compare their capacity to react with the lectin concanavalin-A. Comparative concanavalin-A binding studies were therefore carried out using tritiated lectin and purified $\alpha$-1-antitrypsin from control and protein-deficient animals (Table 3). Although both preparations reacted with concanavalin-A, $\alpha$-1-antitrypsin from the malnourished animals bound significantly more lectin than did the corresponding protease inhibitor from control animals. Because the location of mannose residues in an oligosaccharide chain, as well as the position and nature of substitutions on the sugar, can influence concanavalin-A binding, 


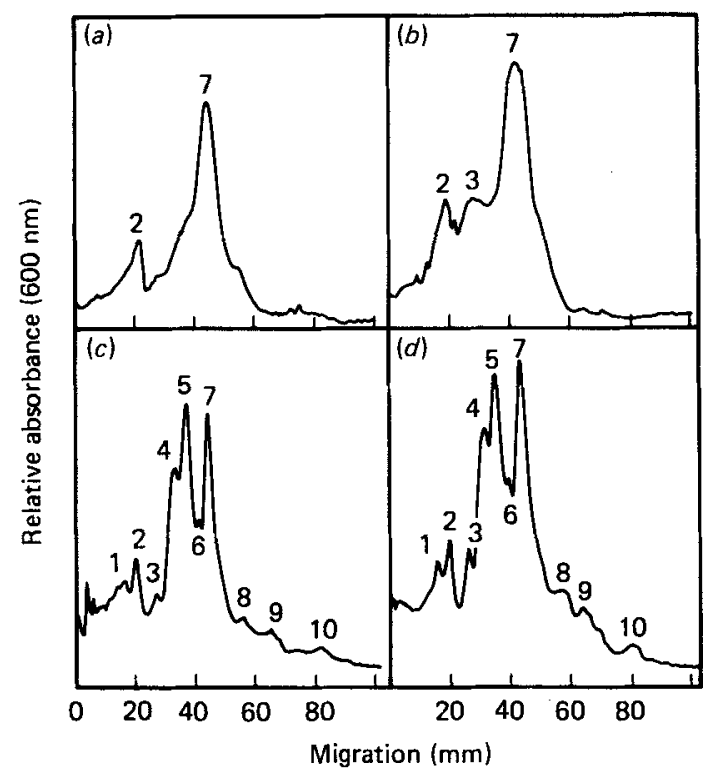

Fig. 3. Analysis of cyanogen bromide cleavage fragments of $\alpha$-1-antitrypsin from control and proteindeficient rats by SDS-polyacrylamide gel electrophoresis. Pure preparations of $\alpha$-1-antitrypsin $(1 \mathrm{mg})$ were cleaved with cyanogen bromide as described on p. 69 . Mixtures of fragments ( $50 \mu \mathrm{g} / \mathrm{lane})$ were subjected to electrophoresis in $2: 8(\mathrm{w} / \mathrm{v})$ polyacrylamide gels according to the method of Laemmli $(1970)$. Duplicate lanes of $\alpha$-1-antitrypsin fragments from control $(a, c)$ and protein-deficient animals $(b, d)$ were stained for carbohydrate $(a, b)$ and protein $(c, d)$ as described on $\mathrm{p}$. 69 . The gel was scanned at $600 \mathrm{~nm}$ with a Gilford linear transport.

Table 3. Comparison of concanavalin-A reactivity and tritium uptake by galactose oxidase (EC 1.1.3.9)-sodium $\left[{ }^{3} \mathrm{H}\right]$ borohydride-treated preparations of $\alpha$-1-antitrypsin from control and protein-deficient rats*

(Mean values and standard deviations)

\begin{tabular}{|c|c|c|c|c|}
\hline \multirow[b]{2}{*}{ Protein } & \multicolumn{2}{|c|}{$\begin{array}{l}\text { Concanavalin-A bound } \\
\text { (counts/min per mg protein) } \\
\times 10^{-4}\end{array}$} & \multicolumn{2}{|c|}{$\begin{array}{c}\text { Tritium uptake from } \mathrm{NaB}^{3} \mathrm{H}_{4} \\
\text { (counts/min per mg protein) } \\
\times 10^{-4} \text { after exposure to } \\
\text { galactose oxidase }\end{array}$} \\
\hline & Mean & SD & Mean & SD \\
\hline$\alpha$-Mannosyl-BSA & 134 & 8 & ND & - \\
\hline$\beta$-Galactosyl-BSA & ND & - & 290 & 21 \\
\hline$\alpha-1$-Antitrypsin from control rats & $2 \cdot 5$ & 0.7 & $<0.3$ & - \\
\hline$\alpha$-1-Antitrypsin from protein-deficient rats & $7 \cdot 8$ & 0.8 & $<0.3$ & - \\
\hline
\end{tabular}

ND, not determined; BSA, bovine serum albumin.

* Control and protein-deficient animals were given 250 and $30 \mathrm{~g}$ casein $/ \mathrm{kg}$ diet respectively for 3 weeks.

we cannot draw any conclusions about the nature of the differences in the structures of the oligosaccharides of the two glycoproteins. Nevertheless, the results of the concanavalin-A experiment do indicate a difference in the carbohydrate domains of the two $\alpha$-1-antitrypsin preparations.

Although the $\alpha$-1-antitrypsin from protein-deficient rats bound three times more 


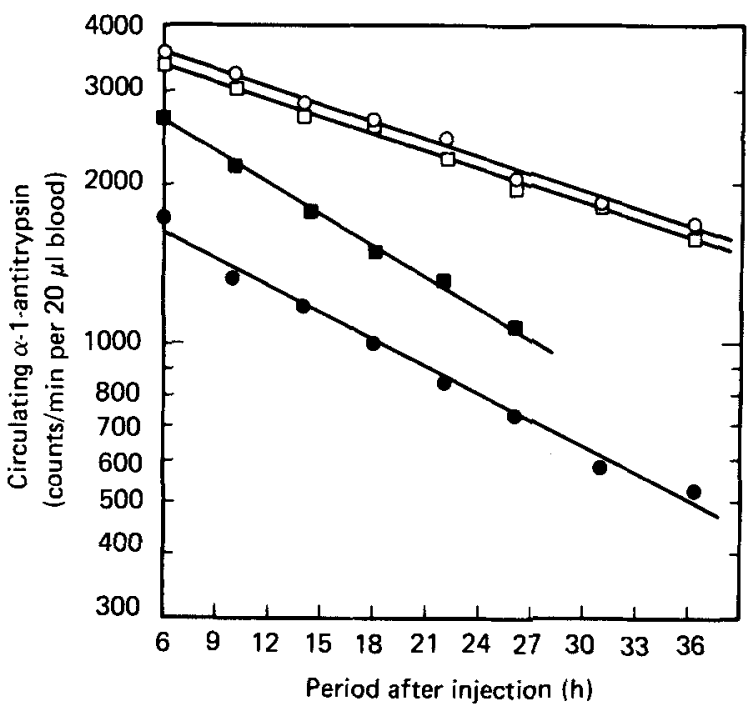

Fig. 4. Clearance of ${ }^{125}$ I-labelled $\alpha$-1-antitrypsin derived from serum of protein-deficient rats from the circulation of control and protein-deficient animals. $\alpha$-1-Antitrypsin purified from the serum of protein-deficient rats was iodinated using $\mathrm{Na}^{125} \mathrm{I}$, diluted with corresponding unlabelled $\alpha$-1-antitrypsin and then injected intravenously into normal and protein-deficient animals as described on p. 65 . The clearance of $\alpha$-1-antitrypsin from the blood is plotted as the amount of labelled $\alpha$-1-antitrypsin (counts $/ \mathrm{min}$ per $20 \mu \mathrm{l}$ blood) remaining in the circulation as a function of time after injection. (O, $(0)$, Clearance of $\alpha$-1-antitrypsin from two representative control rats; $(O, \square)$, clearance after injection of the same glycoprotein into two different protein-deficient animals.

Table 4. Comparison of the fractional catabolic rate of different preparations of $I^{125}$-labelled $\alpha-I$-antitrypsin in control and protein-deficient rats $\dagger$

\begin{tabular}{llllll}
\hline & \multicolumn{4}{c}{ Fractional catabolic rate $(/ \mathrm{h})$} \\
\cline { 2 - 5 } & \multicolumn{2}{c}{ Control } & & \multicolumn{2}{c}{ Protein deficient } \\
\cline { 2 - 5 } Source of $\alpha$-1-antitrypsin & Mean & $n$ & & Mean & $n$ \\
\hline Control rats & 0.0389 & 4 & & $0.0246^{* *}$ & 3 \\
Protein-deficient rats & 0.0418 & 4 & & $0.0234^{* * *}$ & 5 \\
\hline \hline
\end{tabular}

Mean fractional catabolic rates of $\alpha$-1-antitrypsin in control and protein-deficient rats were significantly different (Student's $t$ test): ${ }^{* *} P<0.01, * * * P<0.001$.

$\dagger$ Control and protein-deficient animals were given 250 and $30 \mathrm{~g}$ casein $/ \mathrm{kg}$ diet respectively for 3 weeks.

concanavalin-A than the corresponding glycoprotein from control rats, neither the protease inhibitor from control nor malnourished animals contained exposed galactose residues that might have been labelled by the galactose oxidase- $\mathrm{B}^{3} \mathrm{H}_{4}$ procedure (Table 3 ).

Studies on the fractional catabolic rate of ${ }^{125}$ I-labelled $\alpha$-1-antitrypsin preparations in control and protein-deficient weanling rats. Small changes in the carbohydrate domains of serum glycoproteins can have a marked effect on their fractional catabolic rates (Pricer \& Ashwell, 1976). Studies have shown that in severely protein-energy-malnourished children, plasma albumin is conserved largely as the result of a two- to threefold decrease in its fractional catabolic rate (James \& May, 1968). It is possible that the concentration of 
$\alpha-1$-antitrypsin is maintained in the protein-deficient weanling rats through a conservation mechanism resulting in an increase in the circulating half-life of the protease inhibitor in the blood of the malnourished animals. As shown in Fig. 4 and Table 4, from in vivo studies, we found that the fractional catabolic rate of ${ }^{125}$ I-labelled $\alpha-1$-antitrypsin was greater in the control animals $(0 \cdot 0418 / \mathrm{h})$ than in rats consuming the $30 \mathrm{~g}$ casein $/ \mathrm{kg}$ diet $(0 \cdot 0234 / \mathrm{h})$. The experiment shown in Fig. 4 utilized pure $\alpha$-1-antitrypsin derived from protein-deficient rats and injection was via the tail vein. The same results was obtained using radiolabelled $\alpha$-1-antitrypsin from well-nourished control animals (Table 4); the fractional catabolic rate of control $\alpha$-1-antitrypsin was lower in protein-deficient animals than in control animals $(0.0246 / \mathrm{h} v .0 .0389 / \mathrm{h})$. These results demonstrate that the fractional catabolic rate of $\alpha$-1-antitrypsin is determined by the nutritional status of the animals and not by whatever physical-chemical differences might exist between the $\alpha$-1-antitrypsin preparations from control and protein-deficient rats.

Studies on the secretion of $\alpha-1$-antitrypsin and albumin by perfused rat livers from control and protein-deficient weanling rats. Since changes in rates of synthesis and secretion of proteins by the liver could influence the concentration of plasma proteins, we wanted to compare the ability of livers from control and protein-deficient animals to secrete $\alpha$-1-antitrypsin; to accomplish this goal we utilized the liver perfusion technique (Fig. 5). The amount of $\alpha-1$-antitrypsin secreted into the perfusate was estimated by rocket immunoelectrophoresis. When control animals were fed on the $250 \mathrm{~g}$ casein $/ \mathrm{kg}$ diet for $1-3$ weeks, the rate of secretion of $\alpha-1$-antitrypsin by their livers was independent of age (mean $0.31 \mathrm{mg} \alpha-1$-antitrypsin secreted/g liver per $6 \mathrm{~h}$ ). However, between days 9 and 24, there was a nearly linear increase in the rate of secretion of this glycoprotein by livers from the protein-deficient animals, such that by day 24 the secretion rate for $\alpha-1$-antitrypsin was nearly three times higher for the protein-deficient rats $(0.89 \mathrm{mg} / \mathrm{g}$ liver per $6 \mathrm{~h})$ than for the control animals.

The secretion of $\alpha$-1-antitrypsin by rat liver appears to be the result of de novo glycoprotein biosynthesis rather than the release of stored, preformed material since cycloheximide, an inhibitor of protein synthesis, markedly depressed the secretion rate (Table 5). Tunicamycin also profoundly suppressed the rate of secretion of $\alpha$-1-antitrypsin. Since tunicamycin inhibits the attachment of dolichol lipid-linked oligosaccharide side chains to glycoproteins via $N$-asparagine (Schneider et al. 1978), this result suggests that $\alpha$-1-antitrypsin is not secreted unless the oligosaccharide chains are attached to the polypeptide core of the glycoprotein. This same conclusion was arrived at by Gross et al. (1982) who showed that the rate of secretion of $\alpha$-1-antitrypsin in primary cultures of rat hepatocytes was decreased $60-70 \%$ by tunicamycin. Although tunicamycin has been shown to inhibit the biosynthesis of non-glycoproteins, values presented in the present study suggest that rat $\alpha$-1-antitrypsin is not secreted unless the oligosaccharide chains are attached to the polypeptide core of the glycoprotein. This conclusion is supported by the observation of Geiger et al. (1982) that unglycosylated $\alpha$-1-antitrypsin was secreted at a markedly reduced rate by hepatocytes.

We also estimated the amount of albumin secreted into the perfusion medium, again using the rocket immunoelectrophoresis technique. Livers from control animals secreted an average of 1.95 (sD 0.35) $\mathrm{mg}$ albumin/g liver in $6 \mathrm{~h}$. However, livers from protein-deficient animals fed on the $30 \mathrm{~g}$ casein $/ \mathrm{kg}$ diet for 8-24 d secreted only 0.75 (SD 0.34 ) $\mathrm{mg}$ albumin $/ \mathrm{g}$ liver in $6 \mathrm{~h}$.

Uptake of asialo-orosomucoid and various neoglycoproteins by perfused liver from control and protein-deficient rats. The liver perfusion technique was used to compare the rates of uptake of asialo-orosomucoid and various neoglycoproteins by livers from control and protein-deficient weanling rats. The rate of extraction of ${ }^{125} \mathrm{~J}$-labelled proteins from the 


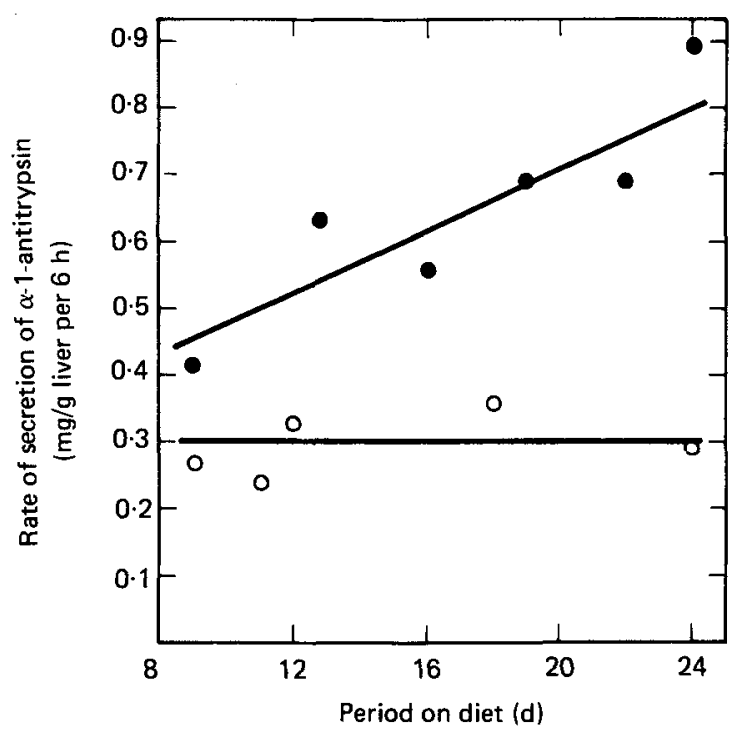

Fig. 5. Secretion of $\alpha$-1-antitrypsin by perfused rat liver as a function of time. Animals were given a ( $O$ ) control or (O) protein-deficient diet $(250$ or $30 \mathrm{~g}$ casein $/ \mathrm{kg}$ diet respectively). The amount of $\alpha$-1-antitrypsin secreted into the perfusion medium was estimated by rocket immunoelectrophoresis (Bieri et al. 1977) using pure rat $\alpha$-1-antitrypsin as the standard.

Table 5. The effect of various compounds on the secretion of $\alpha$-1-antitrypsin by perfused livers from weanling rats fed on the control diet $(250 \mathrm{~g}$ casein $/ \mathrm{kg}$ diet $)$ for $10-20 \mathrm{~d}$

(Mean values and standard deviations)

\begin{tabular}{lcccc}
\hline \hline & \multicolumn{2}{c}{$\begin{array}{c}\text { Rate of secretion } \\
\text { (mg/g liver per 6 h) }\end{array}$} & & $\begin{array}{c}\text { Percentage of } \\
\text { control value }\end{array}$ \\
\cline { 2 - 3 } Addition to perfusion medium & Mean & SD & & $(100)$ \\
\hline None & 0.35 & 0.13 & 21.0 \\
Cycloheximide $(10 \mu \mathrm{g} / \mathrm{ml})$ & 0.073 & 0.057 & 17.1 \\
Tunicamycin $(0.5 \mathrm{mg} / \mathrm{ml})$ & 0.060 & - & \\
\hline \hline
\end{tabular}

perfusion medium by the liver was determined by estimating the amount of tricholoraceticacid-insoluble radioactivity in the perfusate as a function of time. The initial concentration of the particular labelled protein ligand was the same for all of the perfusions, namely 8 $\mu \mathrm{g}$ protein $/ \mathrm{ml}$. In the case of perfused livers from control animals, the galactosyl-containing proteins, asialo-orosomucoid and $\beta$-galactosyl-BSA, werecleared most rapidly; $\alpha$-mannosylBSA was cleared slightly less rapidly than the $\beta$-galactosyl-containing ligands and $\beta$ $N$-acetylglucosaminyl-BSA was cleared at about half the rate of $\alpha$-mannosyl-BSA (Table 6).

Quite different results were obained when similar studies were carried out using livers from animals that were fed on the $30 \mathrm{~g}$ casein $/ \mathrm{kg}$ diet for 2 weeks. The most significant $(P<0.01)$ finding was that $\alpha$-mannosyl-BSA was cleared more rapidly from the perfusion medium than any of the other three ligands studied. The ${ }^{125}$ I-labelled mannose neoglycoprotein was extracted from the perfusion medium nearly three times faster by the livers of protein-deficient animals as compared with control animals (Table 6). The order of 
Table 6. Summary of uptake of various glycoproteins and neoglycoproteins by perfused livers from control and protein-deficient weanling rats $\dagger$

(Mean values and standard deviations. Uptake was measured as described in Materials and Methods. Ligand concentration in the perfusate was $8 \mu \mathrm{g} / \mathrm{ml}$ with a radiospecific activity of $1 \times 10^{4}$ counts $/ \mathrm{min}$ per $\mu \mathrm{g}$ ligand)

\begin{tabular}{|c|c|c|c|}
\hline \multirow[b]{2}{*}{ Ligand } & \multirow[b]{2}{*}{$n$} & \multicolumn{2}{|c|}{$\begin{array}{c}\text { Uptake } \\
\text { (ug protein taken up/ } \\
10 \text { min per g liver) }\end{array}$} \\
\hline & & Mean & SD \\
\hline \multicolumn{4}{|l|}{$\alpha$-Mannosyl-BSA } \\
\hline Control & 5 & $14 \cdot 8$ & $4 \cdot 0$ \\
\hline Protein-deficient & 5 & $46 \cdot 6^{* *}$ & $10 \cdot 0$ \\
\hline \multicolumn{4}{|l|}{ Asialo-orosomucoid } \\
\hline Control & 5 & $21 \cdot 0$ & 4.9 \\
\hline Protein-deficient & 5 & $14 \cdot 5$ & $4 \cdot 2$ \\
\hline \multicolumn{4}{|l|}{$\beta$-Galactosyl-BSA } \\
\hline Control & 4 & $38 \cdot 5$ & $9 \cdot 4$ \\
\hline Protein-deficient & 4 & $32 \cdot 8$ & $7 \cdot 9$ \\
\hline \multicolumn{4}{|c|}{$\beta$ - $N$-Acetylglucosaminyl-BSA } \\
\hline Control & 3 & $8 \cdot 3$ & $4 \cdot 0$ \\
\hline Protein-deficient & 4 & $18 \cdot 4^{* *}$ & $5 \cdot 1$ \\
\hline
\end{tabular}

Significantly different from control (Student's $t$ test); ${ }^{* *} P<0 \cdot 01$.

$\dagger$ Control and protein-deficient animals were given 250 and $30 \mathrm{~g}$ casein $/ \mathrm{kg}$ diet respectively for 2 weeks.

preference for uptake of ligands by livers from the experimental (protein-deficient) animals was: $\alpha$-mannosyl-BSA $>\beta$-galactosyl-BSA $>\beta$ - $N$-acetylglucosaminyl-BSA $>$ asialoorosomucoid. It is noteworthy that there was no significant difference $(P<0 \cdot 1)$ in the rate of uptake of galactose-terminated ligands by livers from control and experimental animals. Also, the rate of extraction of $\beta$ - $N$-acetylglucosaminyl-BSA, which is presumably recognized by the same binding protein as mannosyl-terminated ligands (Townsend \& Stahl, 1981), by livers from protein-deficient animals was not increased to the same extent as that expected from the results obtained with $\alpha$-mannosyl-BSA. Native BSA not conjugated to carbohydrate was not taken up by livers from either group of animals during a $2 \mathrm{~h}$ perfusion period (values not shown).

Although $\alpha$-1-antitrypsin isolated from malnourished animals bound three times more concanavalin-A than did $\alpha$-1-antitrypsin from control animals, the apparent increased reactivity of mannose residues was apparently not reflected in increased uptake of $\alpha-1$-antitrypsin by the mannose-specific hepatic lectin known to reside in Kupffer cells.

\section{DISCUSSION}

The present study was undertaken in an attempt to ascertain the reason why $\alpha$-1-antitrypsin levels are maintained in human protein malnutrition (Omene et al. 1979 b; Schelp et al. 1981). In the present report, we show that, like man, the profoundly protein-deficient young rat is also capable of maintaining blood levels of this protease inhibitor. This maintenance of the protease inhibitory capacity of blood occurs in the face of a decrease in the plasma albumin concentration (Table 1). As indicated by Schelp et al. (1981), these observations document the ability of the protein-malnourished animal to adjust its metabolism so as to preserve certain biochemical indices in the same range as those of healthy animals. 
There is considerable evidence indicating that the principal function of $\alpha$-1-antitrypsin is to neutralize the activity of potentially-damaging elastolytic and collagenolytic enzymes that originate from macrophages of the reticuloendothelial system. The ability to sustain relatively high levels of $\alpha-1$-antitrypsin appears to provide the animal with protection against proteases that might arise in extracellular compartments. It is well-known that elevated serum levels of a number of hydrolases occur as a result of protein malnutrition in man (Omene et al. 1979a) and in the rat (Roobol \& Alleyne, 1974; Glew et al. 1982). Failure to neutralize proteases such as elastase can be quite detrimental, as evidenced by the increased incidence of emphysema in humans who are profoundly deficient in $\alpha$-1-antitrypsin (Kueppers \& Black, 1974).

After rats had been consuming a $30 \mathrm{~g}$ casein $/ \mathrm{kg}$ diet for 4 weeks, the physical-chemical properties of $\alpha$-1-antitrypsin changed. Compared with $\alpha$-1-antitrypsin from healthy rats, the $\alpha$-1-antitrypsin of protein-deficient rats (1) was more acidic (Fig. 1), (2) was slightly larger, (3) had an altered $\mathbf{P}_{i}$ type with a shift to species with lower isoelectric points (Fig. 2), (4) was more reactive to concanavalin-A (Table 3). With the exception of a difference of two to three sialic acid residues, the ratio of the composite sugars of the glycoprotein from malnourished animals was very similar to that observed for $\alpha$-1-antitrypsin from control animals (Table 2). The findings of two to three additional sialic acid residues in $\alpha$-1-antitrypsin from protein-deficient rats could account for its increased anodal mobility and shift in $P_{i}$ type to the more acidic range. We found no significant differences in the amino acid compositions of the two $\alpha$-1-antitrypsin preparations or in the stoichiometry of their interaction with trypsin $(1: 1)$.

Van den Hamer et al. (1970) have shown that removal of as few as two of a total of ten sialic acid residues per molecule is sufficient to reduce the half-life of caeruloplasmin in the circulation from several days to several minutes. Because of the critical biological role of $\alpha-1$-antitrypsin we can only speculate that, in the malnourished state, the additional sialic acid residues may provide some means of insuring the preservation of this protein in the circulation.

Microheterogeneity often occurs at the non-reducing ends of oligosaccharide chains of plasma glycoproteins. The carbohydrate compositional values presented here are probably representative of an average composition. However, random removal of terminal residues giving rise to an average microheterogeneous composition cannot explain the significantly altered $P_{i}$ type of $\alpha$-1-antitrypsin from malnourished animals.

The presence of altered carbohydrate domains of $\alpha$-1-antitrypsin in protein-deficient rats does not alter the rate of clearance of the glycoprotein when injected into the bloodstream of either control or protein-deficient animals (Table 4). The fractional catabolic rate of the protease inhibitor derived from the protein-deficient animals was the same as that of $\alpha$-1-antitrypsin obtained from well-nourished rats. However, we did find that both forms of $\alpha$-1-antitrypsin survive about $50 \%$ longer in the circulation of protein-deficient animals than in control animals. These observations demonstrate that the fractional catabolic rate of $\alpha-1$-antitrypsin can be influenced by the nutritional status of the animal.

Vaughan et al. (1982) have shown that environmental factors, such as stress, can profoundly alter the concentration and proportion of the different isoforms of $\alpha-1$-antitrypsin. These researchers also showed that the acute phase response is associated with a shift of $\alpha$-1-antitrypsin isoforms to species containing increased amounts of sialic acid. Also noteworthy is the fact that the acute phase response is associated with an increase in the level of $\alpha$-1-antitrypsin in plasma. These observations lend support to the idea that an increase in the sialic acid content of $\alpha$-1-antitrypsin may increase the rate of secretion of this glycoprotein from liver. The carbohydrate domains themselves may not play a direct role in determining the rate of secretion of $\alpha$-1-antitrypsin. It is conceivable that the 
additional sialic acid residues modify the tertiary structure of the protein in such a way that intracellular transport and secretion are enhanced. It is also conceivable that malnutrition of the animal constitutes sufficient trauma such that the observations presented here could be the result of an acute-phase response.

The results of our study of the relative rate of extraction of asialo-orosomucoid and neoglycoproteins by perfused livers permit a statement concerning the role of hepatic carbohydrate-specific receptors in the clearance of plasma glycoproteins. In the liver there are at least three sugar-specific receptors: the mannosyl-specific receptor, which also recognizes $N$-acetylglucosaminyl residues, is localized to Kupffer cells (Achord et al. 1978) whereas galactosyl- and phosphomannosyl-specific receptors are contained in hepatocytes (Fisher et al. 1980). Since the perfused liver from a protein-deficient rat clears mannosyl- BSA and galactosyl-BSA two to three times faster than liver from control animals (Table 6), the finding that $\alpha$-1-antitrypsin survives longer in the blood of malnourished animals (Fig. 4) indicates that hepatic mannosyl and galactosyl receptors are not involved in the clearance of $\alpha$-1-antitrypsin. It is conceivable that protein malnutrition causes alterations in other receptors which might be involved in the clearance of $\alpha-1$-antitrypsin; a decrease in such receptors would result in a decrease in the fractional catabolic rate of the molecule. Alternatively, the decrease in the fractional catabolic rate of $\alpha-1$-antitrypsin could be explained by a decrease in the rate of production or release of $\alpha$-1-antitrypsin-specific proteases in the protein-deficient animals. This latter explanation is unlikely because, at least in the human, each of the $\alpha$-1-antitrypsin isoforms comprising the $P_{i}$ type have the same specificity for proteases. If this also holds for the corresponding rat protease inhibitor, then changes in the rate of release of proteases would not alter the $\alpha$-1-antitrypsin $P_{i}$ type in the way we see occurring during protein malnutrition (Fig. 2).

Although we believe that the decreased fractional catabolic rate of the glycoprotein in the blood is a critical factor accounting for the maintenance of $\alpha$-1-antitrypsin levels during protein malnutrition in the rat, the results of our liver perfusion studies (Fig. 5) indicate that an increase in the rate of biosynthesis and secretion of $\alpha$-1-antitrypsin may also contribute to the preservation of this protease defence system in plasma. Whereas the rate of albumin secretion by livers from protein-deficient rats was three times lower than controls, the protein-deficient animals secreted $\alpha$-1-antitrypsin at three times the rate observed for livers from well-nourished control animals. It is conceivable that due to the presence of additional sialic acid residues in the oligosaccharide chain, the $\alpha$-1-antitrypsin molecule in the protein-deficient rat is secreted from the liver more rapidly than the $\alpha$-1-antitrypsin molecule in well-nourished animals.

Certainly, increases in both the rate of synthesis and circulating half-life of $\alpha$-1-antitrypsin cannot occur during protein malnutrition. If this were the case. then the concentration of the protease inhibitor in blood would continuously increase and eventually reach very high levels. It may be that excision of the liver and the perfusion technique itself remove controls which normally act in vivo to prevent the maximum rate of $\alpha$-1-antitrypsin secretion from being achieved. It remains to be seen if the rate of synthesis of $\alpha$-1-antitrypsin is elevated in vivo in protein malnutrition. Finally, it would be worthwhile to pursue experiments that address the control mechanisms and glycosyltransferases involved in the biosynthesis of $\alpha$-1-antitrypsin. The protein-deficient weanling rat should be a good model for such studies.

The authors thank Dr $\mathrm{R}$. Iammarino and Dr $\mathrm{K}$. Brooks for technical assistance in performing electrofocusing. The present investigation was supported by research grant AM-26916 from the United States Public Health Service. 


\section{REFERENCES}

Achord, D. T., Brot, F. E., Bell, C. E. \& Sly, W. F. (1978). Cell 15, 269-278.

Bieri, J. G., Stoewsand, G. S., Briggs, G. M., Phillips, R. W., Woodward, J. C. \& Knapka, J. J. (1977). Journal of Nutrition 107, 1340-1350.

Bradford, M. M. (1976). Analytical Biochemistry 72, 248-254.

Chase, T. \& Shaw, E. (1967). Biochemistry and Biophysical Research Communications 29, 508-514.

Critchley, D. R., Magnani, J. L. \& Fishman, P. H. (1981). Journal of Biological Chemistry 256, 8724-8731.

Davis, B. J. (1964). Annals of the New York Academy of Sciences 121, 404- 427.

Doumas, B. T., Watson, W. \& Briggs, H. G. (1971). Clinica Chimica Acta 31, 87-96.

Eriksson, S. (1965). Acta Medica Scandinavica 117 (Suppl. 432), 1-85.

Fisher, H. D., Gonzalez-Noriega, A., Sly, W. S. \& Morre, D. J. (1980). Journal of Biological Chemistry 255, 9608-9615.

Geiger, T., Northmann, W., Schmelzer, E., Gross, F. \& Heinrich, P. C. (1982). European Journal of Biochemistry 126, 189-195.

Glew, R. H., Diven, W. F., Zidian, J. L., Rankin, B. B., Czuczman, M. \& Axelrod, A. E. (1982). American Journal of Clinical Nutrition 35, 236-249.

Gross, V., Geiger, T., Tran-Thi, T. A., Gauthier, F. \& Heinrich, P. C. (1982). European Journal of Biochemistry 129, 317-323.

Hodges, L. C., Laine, R. \& Chan, S. K. (1979). Journal of Biological Chemistry 254, 8208-8212.

James, W. P. T. \& May, A. M. (1968). Journal of Clinical Investigation 47, 1958-1972.

Jeppsson, J. \& Boel, F. (1982). Clinical Chemistry 28, 219-225.

Kapitany, R. A. \& Zebroswki, E. J. (1973). Analytical Biochemistry 56, 361-369.

Kueppers, F. \& Black, L. F. (1974). American Review of Respiratory Diseases 110, 176-194.

Laemmli, U. K. (1970). Nature 227, 680-685.

Laurell, C. B. (1972). Scandinavian Journal of Clinical Laboratory Investigation 29 (Suppl. 124), 21-37.

Laurell, C. B. (1978). Journal of Chromatography 159, 25-31.

Mancini, G., Carbonara, A. O. \& Heremans, J. F. (1965). Immunochemistry 2, 235-254.

Moore, S. \& Stein, W. H. (1963). Methods in Enzymology 6, 819-831.

Omene, J. A., Adamson, I., Okolo, A. A. \& Glew, R. H. (1979a). Clinical Chimica Acta 91, 213-219.

Omene, J. A., Glew, R. H. \& Ihongbe, J. C. (1979b). East African Medical Journal 56, 263-265.

Pricer, W. E. \& Ashwell, G. (1976). Journal of Biological Chemistry 251, 7539-7544.

Rice, R. H. \& Means, G. E. (1971). Journal of Biological Chemistry 240, 831-832.

Roll, D. E., Aquanno, J. J., Coffee, C. J. \& Glew, R. H. (1978). Journal of Biological Chemistry 253, 6992-6996.

Roll, D. E. \& Glew, R. H. (1981). Journal of Biological Chemistry 256, 8190-8196.

Roobol, A. \& Alleyne, G. A. O. (1974). British Journal of Nutrition 32, 189-197.

Rosenberg, M., Roegner, V. \& Becker, F. (1976). American Review of Respiratory Diseases 113, 779-785.

Salacinski, P., Hope, J., McLean, C., Clement-Jones, V., Sykes, J., Price, J. \& Lowry, P. J. (1979). Proceedings of the Society of Endocrinology 81, 131p.

Schelp, F. P., Pongpaew, P., Sutjahjo, S. R., Supawan, V., Saovakontha, S., Migasena, P. \& Poshakrishna, P. (1981). British Journal of Nutrition 45, 451-459.

Schneider, E. G., Nguyen, H. T. \& Lennarz, W. J. (1978). Journal of Biological Chemistry 253, 2348-2355.

Spackman, D. N., Stein, W. H. \& Moore, S. (1958). Analytical Chemistry 30, 1190-1206.

Takahara, H., Nakayara, H. \& Sinohara, H. (1980). Journal of Biochemistry 88, 417-424.

Takasaki, S. \& Kobata, A. (1976). Methods in Enzymology 50, 50-54.

Townsend, R. \& Stahl, P. (1981). Biochemical Journal 194, 209-214.

Van den Hamer, C. J. A., Morell, A. G., Scheinberg, I. H., Hickman, J. \& Ashwell, G. (1970). Journal of Biological Chemistry 245, 4397-4402.

Vaughan, L., Lorrer, M. \& Carrell, R. W. (1982). Biochimica Biophysica Acta 701, 339-345.

Warburg, O. \& Christian, W. (1941). Biochemischie Zeitschrift 310, 384-421.

Warren, L. (1959). Journal of Biological Chemistry 234, 1971-1975. 